Historic, Archive Document

Do not assume content reflects current scientific knowledge, policies, or practices. 



\section{Offering of}

Choice \& Rare

LILIES

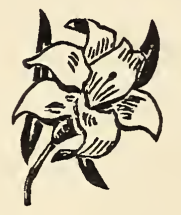

Roberts Rose Company

P. O. Box 277

Englewood, Colorado

Phone South 8163 


\section{Choice and Rare LILIES}

Although lilies are one of the finest garden subjects yet they are shunned by many. When their few cultural requirements are clearly understood they can be grown easily, and they are reliable and hardy.

All lilies are good. As has often been said, it is a family with no poor relations. In a general way, the European lilies are the hardiest and most reliable, when given the right conditions. Even with proper care some of the Japanese lilies are apt to be capricious and, some varieties, such as Auratum, will run out in a few years. The California lilies are very beautiful, but require more shade and moisture than the others, and will stand less freezing. The Native lilies are hardy and usually do well.

Lilies are best planted in clumps in, or at the edge of low growing shrubbery. The best colors will be developed in the flowers, if the afternoon sun does not strike them too strongly.

It pays to prepare the planting place with special care. Their needs are few, but they are very exacting. They must have perfect drainage at all times. This is important, as most of them need considerable moisture. Anything in the way of stagnant water in the winter will kill them. It is well to dust all lily bulbs with fine sulphur before planting, and to set them on a bed of sand. The Japanese lilies can be tipped slightly to one side to keep water from collecting in the bulb and rotting it. Practically all lily bulbs demand light soil; and a mixture of leaf mold, sand and rich garden loam is ideal. A little powered charcoal in the soil is likewise quite desirable. The larger the bulbs, the deeper they should be planted, and with the exception of Candidum and Giganteum, six inches is the minimum.

All lily bulbs are injured to some extent by freezing and the more they can be protected from this the longer their life. It is, therefore, best in all cases when freezing weather has set in, to cover the ground six inches to a foot deep with leaves, litter or old strawy manure. No fresh manure should be used where there is any likelihood of it coming in contact with the bulbs, but well decayed manure can be forked in the bed very freely.

During the growing period, lilies make feeding roots from the stem above the bulb. These come close to the surface and must be protected from drying out. For this purpose, we recommend growing a ground cover.

Some lilies will not bloom the first year, and are all better off if left undisturbed for several years.

Lily bulbs arrive from the growers throughout the fall, the last to come being the Japaneses bulbs. They get here in November and December. Lilies lose strength very rapidly when out of the ground, and we urge immediate planting. We guarantee the safe arrival of sound bulbs when supplied in the fall. Some varieties can be supplied in the spring from cold storage, but not as much can be expected from such late plantings.

We believe the purpose of the average gardener is best served by large bulbs and in every case furnish the largest obtainable. This is not specified throughout the following list, but should be borne in mind in comparing prices. 


\section{JAPANESE LILIUMS}

Auratum. (Golden-banded Lily of Japan). Large, fragrant white flowers dotted crimson; each petal striped goiden yellow; tall grower and blooms late in the summer

Medium sized bulbs $\$ 3.00$ per dozen.

A. Platyphyllum. A much more vigorous form of the preceding. Larger and finer in every way. Flowers spotted yellow.

Large bulbs $\$ 9.00$ per dozen.

A. Rubro Vittatum. Similar to the above, but deep rose pink flowers. Quite a rare variety. A wonderfully beautiful lily

Batemanii. A rather tall growing, large, apricot colored lily, tinged pink. Hardy and easily grown

Elegans. (Thunbergianum). Large, rather flaring orange red spotted flowers on stems about eighteen inches high. These lilies are of the easiest culture. Bloom in June, and vary somewhat in shading and marking..

Large bulbs $\$ 2.50$ per dozen.

Henryi. A fine new lily of bright orange yellow. The long stems carry about twelve reflexed flowers. Quite hardy and very satisfactory........ Large bulbs $\$ 5.00$ per dozen.

Krameri. (Japonica). Large clear fragrant flowers of pink on three foot stems. Must have good drainage. A unique color.

Maximowiczii. This is a later blooming species than most of the red or yellow kinds, and stronger than the yellow variety

Pseudotigrinum. This pretty August flowering species is quite distinct from any other member of the "Tiger Group"; bold racemes of handsome orange scarlet flowers, finely speckled with crimson

Regale. (Myriophyllum). A tall growing hardy white lily, tinged pink, with yellow at the center. Fragrant and carries large clusters of flowers. Blooms in July Large bulbs $\$ 7.50$ per dozen.

Rubellum. A medium sized rose pink, fragrant lily. Grows one and one-half feet high, succeeding in light soil and must have good drainage..........

Speciosum Album. Speciosums are the best of Japanese lilies; hardy and satisfactory. This variety is white with a greenish band on each petal

Large bulbs $\$ 4.00$ per dozen.

Speciosum Album, Kratzeri. A very distinct form. Pure white flowers, with a green band running through the centre of each pedal, rendering it very distinct

S. Rubrum. Similar to the above, but tinged with red. Blooms in August. One of the best known

Large bulbs $\$ 4.00$ per dozen. 
S. Roseum. (Or Melpomene). A deep carmine type of the above

Medium sized bulbs $\$ 3.50$ per dozen.

Large bulbs $\$ 5.00$ per dozen.

S. Magnificum. The largest, strongest growing of all. Deep red

Sulphurgale. Flowers considerably later than Regale, but much like it in growth and appearance. A strong grower

Umbellatem. (Davuricum). An easily grown medium tall lily with rather flaring flowers, varying from orange red to scarlet, dotted black Large bulbs $\$ 3.00$ per dozen.

Wallacei. A splendid August flowering variety. Each bulb produces three to five flowering stems bearing rosy apricot tinted flowers, thickly spotted. Very graceful

Wallichianum superbum. (sulphureum) Immense trumpets, 8 to 9 inches, interior sulphur changing to white and flushed rose, exterior stained purple and deliciously scented

Wilmottiae. This is a new and rare lily. Very floriferous and hardy. In color it is like a shade of orange or technically, it is that of roughe saturne. It blooms with the regale and seems to be quite hardy

\section{EUROPEAN LILIUMS}

Lilium Brownii. This unusual lily has flowers six to eight inches long and nearly as wide. The inside is white, tinged with yellow, but the outside of the petals have purple ribs and is heavily tinged purple. Fragrant and very satisfactory

Candidum. Ascension or Madonna Lily. This is one of the few lilies that will succeed in the full sun. By far the best of the white lilies, and to many, the loveliest of lilies. Ready in September and must be planted at once Large bulbs $\$ 4.00$ per dozen.

Chalcedonicum. Scarlet Turk's-Cap Lily. Another hardy and easily cultured lily, growing moderately high and carrying vermilion-scarlet flowers

Croceum. A handsome, tall growing showy lily. The three to six foot stems carry up to twenty flowers, bright orange yellow spotted purple. Quite hardy

Giganteum. Largest lily in the world. A big strong ten foot stem carrying several white trumpet lilies, each nearly a foot long and as big across. After blooming the bulbs split into several small bulbs, which have to grow a year or two before blooming again. Hardest to get. If they arrive

Hansoni. The earliest of our lilies, with five foot stems carrying many reflexed bright orange flowers. Easily grown, but requires light loam

Marhan. A pretty hybrid resembling Martagon Album in general appearance with the thick petals of Hansoni. The color is a remarkable one, rich orange, lined and spotted with reddish brown, growing 6 to 7 feet high 
Martagon. European Turk's-Cap Lily. Tall growing, many flowered lily, with deep claret reflexed flowers. Hardy and easily grown. Fall planting necessary

M. Album. Similar to the above, but pure white. A fine unusual lily. Will stand much shade.

Martagon Dalmaticum. Strong growing, stately lily; the stems rise as high as 6 feet, with correspondingly large flower clusters. Deep vinous purple of waxy texture and they shine as if varnished

Monadelphum Szovitzianum. One of the finest yellow lilies, long stems with pyramidal clusters of deep yellow reflexed flowers. Fall planting is necessary, and it will not do much the first year

Pyrenaicum. Very distinct species from thePyrenees, growing 3 feet, dense foliage. Yellow heavily spotted

Sargentiae. In the very front rank of hardy lilies. The flowers are funnel shaped, milk white internally with yellow throat, and deep reddish brown externally, very fragrant. July flowering

Testaceum. An extremely graceful tall growing lily, carrying large clusters of dull apricot flowers. Quite hardy and grows vigorously. Fall planting is necessary

Thomsonianum. A very distinct species, slender spikes of pale mauve flowers. Leaves like a Hemerocallis, mostly crowded at the base of the stems. Very unique

\section{CALIFORNIA LILIUMS}

Bolanderi. 1 to 3 feet high, slender, with bell shaped, deep crimson red flowers, dotted purple. Blooms in late June and July

Burbankii. Best described as a strong growing Pardalinum, stout leafy stems, with 15 to 30 fragrant flowers, crimson flushed orange, spotted chocolate

Columbianum. A low growing, bright golden yellow lily, with maroon spots. Good.

Humboldtii. The finest of the California lilies. Tall growing, up to a maximum of ten feet. Orange red flowers, with small maroon spots. Does well in heavy soils and in heavy shade....

H. Magnificum. Similar to the preceding, but a better grower and the spots surrounded by a circle of crimson.

H. Bloomerianum. Similar to the preceding, but smaller stemmed, with smaller flowers. Very pretty

Kelloggii. A pink lily, growing medium high, slender stemmed, but carrying numerous reflexed flowers. Very fragrant

Maritimum. A rare, but beautiful bog lily; deepest crimson flowers, dotted lightly in the throat. Grows medium high, and blooms in July... 
Pardalinum. Best described as the Tiger Lily of California. Tall grower, and succeeds in any moist. soil. The reflexed flowers have orange centers and crimson tips.

Parryi. This is one of California's finest. Grows three to five feet high, and bears many trumpet shaped, fragrant yellow flowers. Must have a wet place

Parvum. Tall growing lily with many small orange crimson tipped, bell-shaped flowers. A fine lily for moist soil

Parvum Luteum. A taller growing variety of the above, with clear yellow flowers

Roezlii. A tall, slender stemmed, reddish orange lily. Should be grown in clumps for best effect. Quite rare. Requires moist soil.

Roezlii. (Crimson form). Much like the above, but the flowers are deep blood red.

Rubescens. A very beautiful and distinct kind, having tall stems, and fragrant tabular flowers. As the flowers age, purple dots and blotches appear until they are all purple. The drainage must be perfect.

Washingtonianum Purpureum. A very choice lily, shading from white to rich wine color. Tall growing and bearing many flowers. The bulbs will not bloom well the first year, and they are uncertain unless given the best cultural conditions

\section{NATIVE LILIUMS}

Canadense. Yellow to orange drooping flowers, spotted inside, requiring a shady moist place; must be planted in the fall

Large bulbs $\$ 2.50$ per dozen.

Grayi. Flowers are dark orange red, fine for cutting to go with white flowers

Pardal-Parryi. These pretty hybrids are very variable in color, formation and time of flowering; predominant color is rich orange yellow, shaded, spotted and margined crimson

Philadelphicum. Cup shaped yellow flowers, tipped scarlet and dotted maroon. Must have leaf mold and shade and should be planted in the fall

Large bulbs $\$ 2.50$ per dozen.

Superbum. A red, yellow to crimson spotted, tall growing lily. Must have good soil, shade and considerable moisture. Fall planting

Large bulbs $\$ 2.50$ per dozen.

Tenuifolium. A beautiful little reflexed scarlet lily. The short stems carrying fifteen to thirty flowers. Must have a cool, moist, shady location

Large bulbs $\$ 3.00$ per dozen.

Thayerae. Flowers orange red, heavily spotted dark purple. Perfectly hardy 
Tigrinum Splendens. The common Tiger Lily. Large reflexed orange red flowers, spotted purple. Will do well in a great variety of locations

Large bulbs $\$ 2.00$ per dozen.

Tigrinum Flore Pleno. A double form of the above. The best double in commerce.

Large bulbs $\$ 2.50$ per dozen.

Tigrinum Fortunei. Crowded heads large open flowers, brilliant scarlet, freely spotted black........ Large bulbs $\$ 3.00$ per dozen.

All lily orders are accepted subject to the arrival of the bulbs in good condition.

We believe the purpose of the average gardener is best served by large bulbs and in every case furnish the largest obtainable. This is not specified throughout the above list, but should be borne in mind in comparing prices.

In addition to Lilies, we offer a great variety of the best in

\section{HARDY PERENNIALS PEONIES IRIS PHLOX ROSES}

\section{DELPHINIUMS}

We have specimens of them all growing in our garden for your inspection. The best of the old, and the new and unique are all here. One part of this garden is even devoted to rock and Alpine plants where these rare little gems thrive wonderfully.

It is our aim to show in this garden everything in the way of hardy plants that can be grown successfully in this climate. We seek the new plants that they may be tested beside the things our Grandmothers knew. The range of plants available for use in Colorado is amazingly great. All that we learn from these plants regarding their cultural requirements is carefully recorded. This information is for your use at any time.

OUR GARDEN IS LOCATED AT 3450 SOUTH EMERSON STREET, JUST EAST OF ENGLEWOOD.

We are now in a position to give cultural information of any kind from our experience in regard to any plants. Write, phone or call on us for anything you want to know. From time to time cultural leaflets will be sent out on special subjects to those indicating their interest in such subjects.

Descriptive lists of any of the above gladly furnished.

\section{ROBERTS ROSE COMPANY}

\section{Gardens on South Emerson Street at East Hampden Avenue East of Englewood}

P. 0. Box 277, Englewood, Colorado 


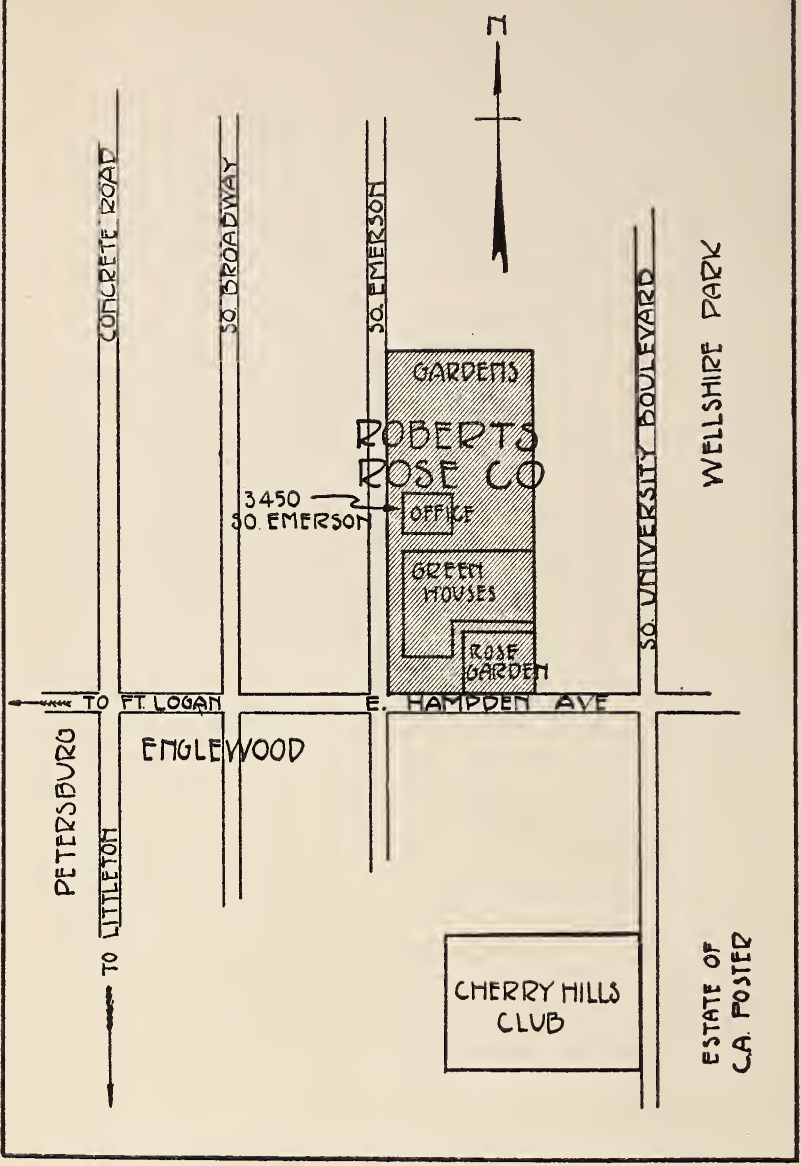

How to Get to the

\section{PERENNIAL GARDENS}

\section{of the}

\section{Roberts Rose Company}

Go south on Broadway to Englewood. Turn east on Hampden, the main corner, to Emerson Street where you will see the large greenhouses. Or go south on South University to the road beyond Wellshire Park. Turn west to Emerson Street. Here you will see Lilies, Peonies, Iris, Phlox and all other hardy plants growing in immense variety. A visit is an education. Phone South 8163 or drive out. 